\title{
Conceptual frameworks for programs addressing violence against children: a scoping review*
}

\author{
Bases conceituais orientadoras dos programas de enfrentamento da violência contra \\ a criança: revisão de escopo \\ Bases conceptuales orientadoras de programas de enfrentamiento de violencia \\ contra el niño: revisión de alcance
}

How to cite this article:

Macedo CM, Egry EY. Conceptual frameworks for programs addressing violence against children: a scoping review. Rev Esc Enferm USP. $2021 ; 55: e 20200182$. DOI: https://doi.org/10.1590/1980-220X-REEUSP-2020-0182

\section{Cibele Monteiro Macedo ${ }^{1}$ \\ Emiko Yoshikawa Egry²}

* Extracted from "Bases conceituais orientadoras dos programas de enfretamento da violência contra a criança na Atenção Primária: revisão de escopo”, Escola de Enfermagem, Universidade de São Paulo, 2019.

${ }^{1}$ Universidade de São Paulo, Escola de Enfermagem, Programa de Pós-Graduação em Enfermagem, São Paulo, SP, Brazil.

${ }^{2}$ Universidade de São Paulo, Escola de Enfermagem, Departamento de Enfermagem em Saúde Coletiva, São Paulo, SP, Brazil.

\section{ABSTRACT}

Objective: Map the conceptual frameworks for programs addressing violence against children developed in primary health care. Method: This is a scoping review that followed the methodological recommendations of the Joanna Briggs Institute. A reference manager and qualitative analysis software were used for data management and analysis. Results: 1,346 studies were pre-selected and analyzed. The final sample consisted of 24 studies, mostly published in the 2000s. Three strategic actions were identified in programs: Home Visitation, Children Exposed to Violence, and Parenting Development, most of them focused on the level of intervention. No study explained the conceptual frameworks guiding the programs. Conclusion: Mapped programs were well structured and essential for addressing domestic violence against children. They mainly adopted the multi-causal concept to understand the healthdisease process, which was restricted to overcoming the contradictions of violence.

\section{DESCRIPTORS}

Domestic Violence; Child Abuse; Primary Health Care; Public Health; Review; Nursing. 


\section{INTRODUCTION}

Violence, as a historical, social, dialectical, and dynamic phenomenon, is present in different ways in various social groups. Violence is closely linked with social inequality, including gender inequality and inter-generational inequality ${ }^{(1)}$.

In recent decades, several international organizations have highlighted the strong impact of violence on global economies and its serious consequences for individuals, families and society, especially when committed against children. For the World Health Organization (WHO), violence against children and adolescents refers to all forms of emotional and/or physical abuse, neglect, sexual abuse or other forms of exploitation that may result in potential or actual harm to the health of children and adolescents ${ }^{(2)}$.

According to the United Nations International Children's Emergency Fund (Unicef), 82,000 deaths of boys and girls aged 10 to 19 years were reported across the world in 2015. Among these deaths, 51,300 were not related to armed conflicts ${ }^{(3-4)}$.

Data published in 2015 show that six out of ten children (about 250 million) between 12 and 23 months of age are subjected to violent discipline. "Almost half suffer physical punishment and a similar proportion are exposed to verbal abuse $^{(4)}$." According to data from Unicef, 300 million children (three out of four) aged two to four years worldwide regularly suffer violent discipline (with physical force or verbal intimidation) by their caregivers ${ }^{(3-4)}$.

According to Unicef, "children and adolescents experience violence across all stages of childhood and adolescence, in diverse settings, and often at the hands of the trusted individuals with whom they interact daily."(3)

The invisibility and underreporting of cases of violence against children is seen in a report published in 2016 by the WHO, which shows that a significant proportion of deaths generated by violence against children is inadequately attributed to falls, burns, drowning, and other causes ${ }^{(5)}$.

Actions addressing violence show the need to restructure services, implement changes in work routine of professionals, and the importance of developing interdisciplinary and multidisciplinary actions that are not limited to the biological or singular dimension of the phenomenon ${ }^{(6-7)}$. Such restructuring must include a social support network in partnership with the community and be based on operational and local studies ${ }^{(7)}$.

Studies point to the potential of primary health care (PHC) for the development of actions to address violence, due to the proximity to families and the geopolitical space in which they are inserted ${ }^{(8-10)}$. However, the global scientific literature shows some barriers to addressing violence, including actions lacking theoretical and conceptual support, medicalization of violence due to the obstacles for handling its social aspects, work organization and structuring based on numerical goals, and policies and strategies based on a market logic that does not provide conditions and governability over all social determinations of the phenomenon of violence ${ }^{(8,11-13)}$.
Health actions performed today "will respond to the hegemonic political projects of the capitalist State that is masked as responses to social demands ${ }^{(14)}$ ". For this reason, phenomena of social determinations, such as violence, which need actions that promote changes in social production and reproduction, are contrary to the capitalist State and, therefore, will never be seen in its totality.

Authors from Nursing in Collective Health observe that violence must be analyzed through robust theoretical frameworks and conceptual categories, such as gender and generational, to detect more vulnerable social groups that urgently need public policies to address violence ${ }^{(15)}$, allowing effective actions to address violence against children. This process highlights the need to clarify the theoretical and conceptual frameworks of programs addressing violence, as this process helps overcome challenges ${ }^{(16)}$.

Given the potential of PHC for the development of actions to address violence and the need to clarify the theoretical and conceptual frameworks of the programs, this study aims to map the conceptual frameworks of programs addressing domestic violence against children developed within the scope of PHC.

\section{METHOD}

\section{Type OF Study}

This is a scoping review, which followed the methodological recommendations suggested by the Joanna Briggs Institute and had the contribution of the Brazilian Center for Evidence-Based Health Care: an affiliate of the Joanna Briggs Institute (JBI - Brazil). Scoping reviews are used to map key concepts, analyze existing evidence before conducting a systematic review, clarify, and define conceptual limits ${ }^{(17)}$.

This study was inspired by the theoretical and philosophical frameworks of public health and its analytical categories, with special emphasis on the categories of gender and generation, which emerge from the phenomenon of violence against children ${ }^{(18)}$.

The guiding question of this study was developed according to the PCC (population, concept, context) strategy, recommended for scoping reviews, in which $\mathrm{P}$ referred to children, $\mathrm{C}$ referred to conceptual frameworks, and $\mathrm{C}$ referred to primary health care. Then, the guiding question of this review was: "What are the conceptual frameworks of programs addressing domestic violence against children in primary health care?" A preliminary search in PROSPERO, MEDLINE, Cochrane Database of Systematic Reviews, the Joanna Briggs Institute Database of Systematic Reviews and Implementation Reports, and Campbell, and no review was found with the same guiding question.

\section{Selection Criteria}

The bibliographic search strategy was comprehensive, including published and unpublished studies, and used the following keywords, descriptors in health sciences, and MeSH (Medical Subject Headings of the U.S. National Library of Medicine) and/or synonymous descriptors 
combined with each other according to each database in English, Portuguese and Spanish: violence; domestic violence; intrafamily violence; child maltreatment; children OR child; childhood; health practices; professional practice; actions; programs; intervention; intervention programs; strategy; government program; multidisciplinary team; coping; coping strategy; primary attention; primary care; preventive health. The review included studies published in English, Spanish and Portuguese, without time restrictions, which described programs addressing domestic violence against children aged 0 to 12 years, developed in the PHC.

\section{Data Collection}

The search for studies was conducted from May to October 2018 in thirteen databases from different areas of knowledge, which are: MedLine (PubMed), ERIC (Educational Resources Information Center), PsycINFO (American Psychological Association), CINAHL (Cumulative Index to Nursing and Allied Health Literature), Web of Science, SciELO, LILACS, IPSCAN (International Society for the Prevention of Child Abuse and Neglect), SCOPUS, and IBSS. The search for gray literature was conducted in the following databases: Google Scholar; OpenGrey; NYAM Grey Literature.

\section{Data Analysis and Treatment}

Study titles and abstracts, when available, were read in full, searching for the words: primary care, violence, and child, and analyzed by the reviewer in order to identify eligible studies for the review. In situations with doubts about study eligibility, the study was maintained for the next study phase. After that, pre-selected studies were read in full; if the study was relevant to the guiding question, data of interest were extracted.

Mendeley ${ }^{\circledR}$ reference manager and webQDA ${ }^{\circledR}$ qualitative analysis software were used for better management, organization and codification of studies. Quantitative findings were analyzed using Excel ${ }^{\circledR} 2016$ and qualitative findings were assessed by a content analysis ${ }^{(19)}$.

\section{RESULTS}

The search identified a total of 7,206 studies in the databases; the studies were pre-selected according to title and abstract and exported to the Mendeley ${ }^{\circledR}$ software. Documents that were not fully available online and duplicates were excluded; and 572 studies were read in full. Of these, 548 studies were excluded because: they had theoretical discussions about programs addressing violence against children ( $n=189$ ); they were not developed within the scope of PHC ( $\mathrm{P}=30)$; they reported programs addressing violence against children developed with professionals and not with children, the target population of our study $(n=320)$; and they did not cover the age group defined in the inclusion criteria $(n=9)$. Then, 24 studies were included in the review, most of them from the PubMed database (MedLine). Table 1 shows the study selection and exclusion process in a PRISMA flow diagram ${ }^{(20)}$.

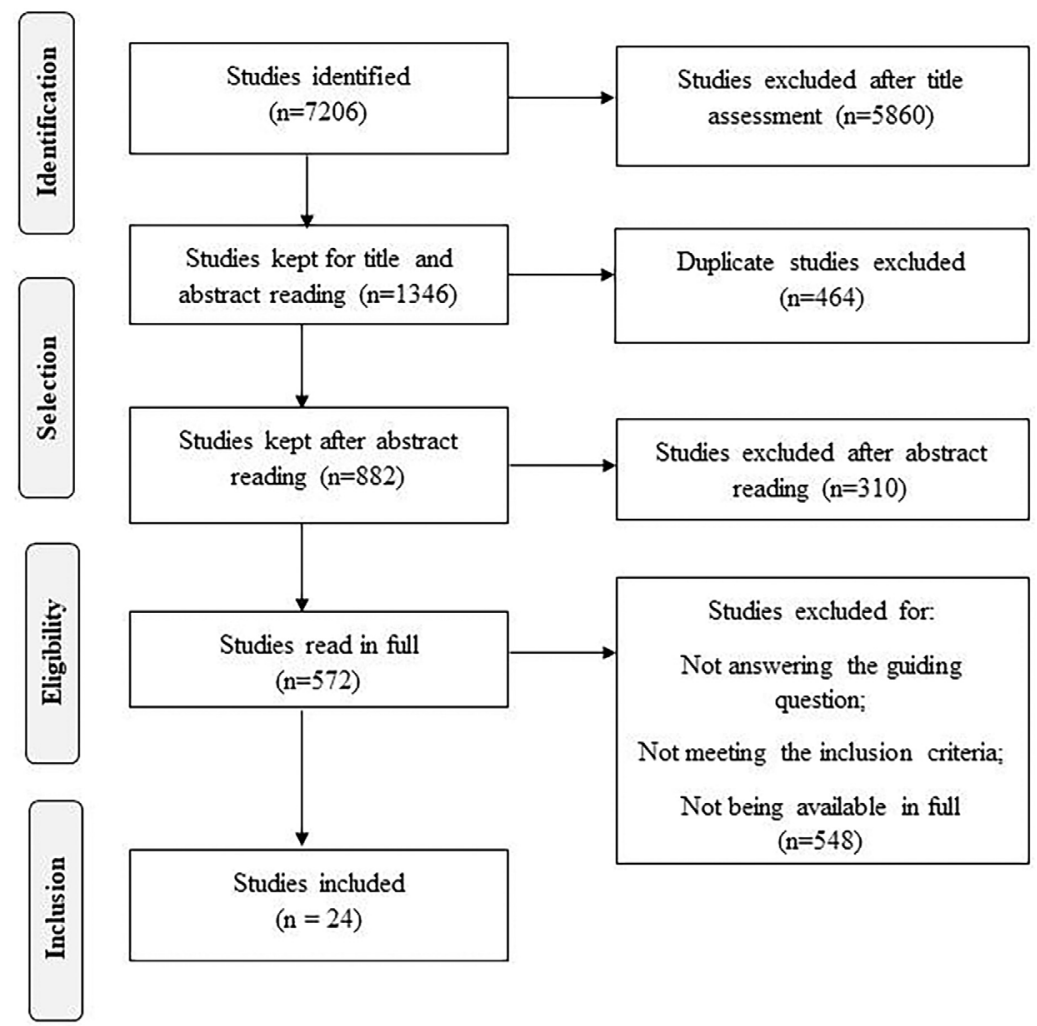

Figure 1 - PRISMA flow diagram illustrating the study selection process ${ }^{(20)}$. 
Table 1 - Studies included in the scoping review by database. São Paulo, SP, Brazil, 2018.

\begin{tabular}{lc}
\hline Database & Number of studies \\
\hline PubMed & 11 \\
Scopus & 6 \\
Gray literature & 5 \\
PsyINFO & 1 \\
IBSS & 1 \\
\hline Total & 24 \\
\hline
\end{tabular}

All studies included in the review were published in English; 12 were developed in the United States of America (USA), one in Canada, two in Scotland, two in England, two in Japan, two in Australia, one in the Netherlands, one in New Zealand, and one in Russia. Most of them $(n=16)$ were published in 2000-2010, seven studies in 2011-2019, and one study in 1980-1999.

No study from Latin America was included. It may be due to the lack of studies about programs addressing domestic violence against children developed in $\mathrm{PHC}$ published in journals or the absence of these actions.

To answer the guiding question, first we had to map the programs addressing domestic violence against children developed in primary health care and understand their objectives, strategies, and the main limitations and potentialities. For this reason, the programs addressing violence against children incorporated in this review were classified according to the objective proposed by the program and the strategy used to meet the objectives.

The objectives of the programs were defined as: prevention of violence against children; and identification of situations of violence and intervention in situations of violence against children. The main strategies used to achieve the objectives were: Home Visitation, which are programs that generally cover the family as a whole; Parenting Development, programs that seek to develop healthy relationships within the family; and Programs with Children Exposed to Violence, focused on the child victim of violence and overcoming the consequences of violence, such as depression and violent behavior. Some programs were classified under more than one goal and strategy.

Most programs were focused on prevention $(n=15)$ and intervention $(n=15)$ in the situation of violence with emphasis on the child or family, either in the prenatal period, to prevent children from experiencing future situations of violence, or in direct intervention with children (to interfere in the cycle of violence) so that they do not become future perpetrators of violence.

Chart 1 describes the studies included in the review, the programs, their objectives and strategies.

Home Visitation programs were highlighted as programs to identify and prevent violence, and were focused on the family, mainly mothers and children; while the programs for Children Exposed to Violence and Parenting Development were mostly interventions focused only on children or just caregivers. Chart 2 describes the main limitations and potentialities, according to each strategy.

\section{Conceptual Frameworks}

No study explicitly described the conceptual frameworks of programs addressing violence. In an attempt to make this identification, we sought to understand the concepts of health-disease, violence and childhood found in the studies and presented in the excerpts below, which are essential concepts to help explain the phenomenon of domestic violence against children, and correlate them to the main currents of interpretation of the health-disease process ${ }^{(45)}$. The excerpts in quotation marks are part of the articles that constituted the sample and were translated by the authors.

Although not clearly described, programs addressing domestic violence against children showed a predominance of the multi-causal concept. The programs are based on the morbidity and mortality profiles of children and families to identify the most vulnerable families in a risk-based perspective and a linear conception of the health-disease process. The most vulnerable social groups were recognized through the identification of risk factors using standardized instruments. It provides an understanding of the health-disease process based on multi-causal aspects, focused on disease and symptomatology:

"We believe this intervention offers an opportunity to avoid recognized neurological and psychological vulnerabilities presented by children when they are exposed to ongoing violence." ${ }^{(44)}$

"A number of risk factors are associated with child maltreatment, including, but not limited to, young single or non-biological parents; lack of parental understanding of children's needs, child development or parenting skills; abusive parent-child relationships or negative interactions; parental thoughts or emotions that support violent discipline; family dysfunction or violence; parent history of abuse or neglect in the family of origin; substance abuse within the family; social isolation, poverty or other socioeconomic disadvantages; and parent stress and anguish." ${ }^{(44)}$

"The Tool to Measure Parenting Self-Efficacy (TOPSE) assesses parent programs and takes into account the opinions and experiences of parents from different cultural and social backgrounds." ${ }^{(30)}$

The social aspect of the phenomenon of violence is understood as the sum of factors related to low income, low education level, and poor access to health services.

"High risk for child abuse (...) families with low education level, low income, limited social support (...) referred to social services." ${ }^{(43)}$

"Child maltreatment is a major public health problem that has long-term consequences for mental and physical health and can lead to death. We studied the effect of a nurse home visitation program for child maltreatment among disadvantaged young families in the Netherlands." ${ }^{(29)}$ 
Chart 1 - Characteristics of studies, description of programs, their objectives and strategies. São Paulo, SP, Brazil, 2018.

\begin{tabular}{|c|c|c|c|c|c|c|c|}
\hline Authors & Year & Country & Design & Program & Objective & Target population & Strategy \\
\hline Bunston $\mathrm{W}^{(21)}$ & 2006 & Australia & $\begin{array}{l}\text { Study showing } \\
\text { before/after the } \\
\text { intervention }\end{array}$ & Peek-a-boo Club & $\begin{array}{l}\text { Prevention and } \\
\text { intervention }\end{array}$ & $\begin{array}{l}\text { Mothers and children } \\
(0-3 \text { years }) \text { exposed } \\
\text { to domestic violence }\end{array}$ & $\begin{array}{l}\text { Parenting } \\
\text { development } \\
\text { programs }\end{array}$ \\
\hline $\begin{array}{l}\text { Finkelstein } \\
\text { et al. }{ }^{(22)}\end{array}$ & 2005 & USA & $\begin{array}{l}\text { Mixed methods } \\
\text { (cross-sectional } \\
\text { and qualitative } \\
\text { studies) }\end{array}$ & - & Intervention & $\begin{array}{l}\text { Children (5-10 years) } \\
\text { and mothers using/ } \\
\text { abusing alcohol and } \\
\text { drugs }\end{array}$ & $\begin{array}{l}\text { Parenting } \\
\text { development } \\
\text { program, } \\
\text { Program for } \\
\text { children exposed to } \\
\text { violence }\end{array}$ \\
\hline $\begin{array}{l}\text { Puccia E, } \\
\text { et al. }{ }^{(23)}\end{array}$ & 2012 & USA & $\begin{array}{l}\text { Study showing } \\
\text { before/after the } \\
\text { intervention }\end{array}$ & $\begin{array}{l}\text { Trauma-Focused } \\
\text { Cognitive } \\
\text { Behavioral } \\
\text { Therapy }\end{array}$ & Response & $\begin{array}{l}\text { Children exposed to } \\
\text { domestic violence }\end{array}$ & $\begin{array}{l}\text { Program for } \\
\text { children exposed to } \\
\text { violence }\end{array}$ \\
\hline Sharp, J ${ }^{(24)}$ & 2011 & Scotland & Action research & Cedar Program & $\begin{array}{l}\text { Intervention } \\
\text { and response }\end{array}$ & $\begin{array}{l}\text { Mothers and children } \\
\text { exposed to domestic } \\
\text { violence }\end{array}$ & $\begin{array}{l}\text { Program for } \\
\text { children exposed to } \\
\text { violence, Parenting } \\
\text { development } \\
\text { program }\end{array}$ \\
\hline Crusto et al. ${ }^{(25)}$ & 2008 & USA & $\begin{array}{l}\text { Randomized } \\
\text { clinical study }\end{array}$ & $\begin{array}{l}\text { Child and Family } \\
\text { Interagency } \\
\text { Resource, Support, } \\
\text { and Training } \\
\text { Program - Child } \\
\text { FIRST }\end{array}$ & Intervention & $\begin{array}{l}\text { Ethnically diverse } \\
\text { children (1-6 years) }\end{array}$ & $\begin{array}{l}\text { Program for } \\
\text { children exposed to } \\
\text { violence, } \\
\text { Parenting } \\
\text { development } \\
\text { program }\end{array}$ \\
\hline Child Trends $^{(26)}$ & 2016 & Russia & $\begin{array}{l}\text { Randomized } \\
\text { clinical study }\end{array}$ & $\begin{array}{l}\text { Trauma-Focused } \\
\text { Cognitive } \\
\text { Behavioral } \\
\text { Therapy (TF-CBT) }\end{array}$ & Intervention & $\begin{array}{l}\text { Children ( } 3-11 \text { years) } \\
\text { and mothers }\end{array}$ & $\begin{array}{l}\text { Program for } \\
\text { children exposed to } \\
\text { violence }\end{array}$ \\
\hline $\begin{array}{l}\text { Becker, Mathis, } \\
\text { et al. }{ }^{(27)}\end{array}$ & 2008 & England & $\begin{array}{l}\text { Study showing } \\
\text { before/after the } \\
\text { intervention }\end{array}$ & Haupoa Program & Intervention & $\begin{array}{l}\text { Children (3-11 years) } \\
\text { of Asian origin and } \\
\text { American children } \\
\text { from the Pacific } \\
\text { Island and parents }\end{array}$ & $\begin{array}{l}\text { Program for } \\
\text { children exposed to } \\
\text { violence, Parenting } \\
\text { development } \\
\text { program }\end{array}$ \\
\hline $\begin{array}{l}\text { The California } \\
\text { Evidence- } \\
\text { Based } \\
\text { Clearinghouse } \\
\text { for Child } \\
\text { Welfare }^{(28)}\end{array}$ & 2016 & USA & & $\begin{array}{l}\text { Kids' Club } \\
\text { and Moms' } \\
\text { Empowerment }\end{array}$ & Intervention & $\begin{array}{l}\text { Children ( } 6-12 \text { years) } \\
\text { and mothers }\end{array}$ & $\begin{array}{l}\text { Program for } \\
\text { children exposed to } \\
\text { violence }\end{array}$ \\
\hline $\begin{array}{l}\text { Mejdoubi J, } \\
\text { et al. }{ }^{(29)}\end{array}$ & 2015 & $\begin{array}{l}\text { The } \\
\text { Netherlands }\end{array}$ & $\begin{array}{l}\text { Randomized } \\
\text { clinical study }\end{array}$ & VoorZorg & $\begin{array}{l}\text { Prevention and } \\
\text { intervention }\end{array}$ & $\begin{array}{l}\text { Children }(0-2 \text { years }) \\
\text { and pregnant } \\
\text { mothers }\end{array}$ & $\begin{array}{l}\text { Home visitation } \\
\text { program, Parenting } \\
\text { development } \\
\text { program }\end{array}$ \\
\hline $\begin{array}{l}\text { Kendall S, } \\
\text { et al. }{ }^{(30)}\end{array}$ & 2013 & Japan & $\begin{array}{l}\text { Exploratory quasi- } \\
\text { experimental study }\end{array}$ & 123Magic & Intervention & $\begin{array}{l}\text { Children ( } 2-12 \text { years) } \\
\text { and parents }\end{array}$ & $\begin{array}{l}\text { Home visitation } \\
\text { program, Parenting } \\
\text { development } \\
\text { programs }\end{array}$ \\
\hline $\begin{array}{l}\text { Crisp BR, } \\
\text { et al. }{ }^{(31)}\end{array}$ & 2004 & Scotland & $\begin{array}{l}\text { Qualitative study, } \\
\text { thematic analysis } \\
\text { of interviews }\end{array}$ & - & $\begin{array}{l}\text { Identification } \\
\text { and prevention }\end{array}$ & $\begin{array}{l}\text { Children and } \\
\text { mothers }\end{array}$ & $\begin{array}{l}\text { Parenting } \\
\text { development } \\
\text { programs }\end{array}$ \\
\hline $\begin{array}{l}\text { MacMillan HL, } \\
\text { et al. }{ }^{(32)}\end{array}$ & 2005 & Canada & $\begin{array}{l}\text { Randomized } \\
\text { clinical study }\end{array}$ & $\begin{array}{l}\text { Programme of } \\
\text { home visitation } \\
\text { by nurses }\end{array}$ & Prevention & $\begin{array}{l}\text { Families with a } \\
\text { history of domestic } \\
\text { violence against } \\
\text { children }\end{array}$ & $\begin{array}{l}\text { Parenting } \\
\text { development } \\
\text { programs }\end{array}$ \\
\hline $\begin{array}{l}\text { Kayama M, } \\
\text { et al. }{ }^{(33)}\end{array}$ & 2004 & Japan & $\begin{array}{l}\text { Qualitative (focus } \\
\text { group) }\end{array}$ & - & Prevention & $\begin{array}{l}\text { Mothers and children } \\
\text { (under } 6 \text { years old) }\end{array}$ & $\begin{array}{l}\text { Parenting } \\
\text { development } \\
\text { program }\end{array}$ \\
\hline $\begin{array}{l}\text { Kelleher L, } \\
\text { et al. }{ }^{(34)}\end{array}$ & 2004 & Australia & $\begin{array}{l}\text { Quantitative- } \\
\text { descriptive } \\
\text { comparative }\end{array}$ & $\begin{array}{l}\text { Cottage } \\
\text { Community Care } \\
\text { Pilot Project }\end{array}$ & & 25 families & $\begin{array}{l}\text { Parenting } \\
\text { development } \\
\text { program }\end{array}$ \\
\hline $\begin{array}{l}\text { Bugental DB, } \\
\text { et al. }{ }^{(35)}\end{array}$ & 2009 & USA & $\begin{array}{l}\text { Randomized } \\
\text { clinical study }\end{array}$ & $\begin{array}{l}\text { Healthy Start } \\
\text { home visitation }\end{array}$ & Intervention & $\begin{array}{l}\text { Families with } \\
\text { newborn children }\end{array}$ & $\begin{array}{l}\text { Home visitation } \\
\text { program, Parenting } \\
\text { development } \\
\text { program }\end{array}$ \\
\hline
\end{tabular}

continue... 


\begin{tabular}{|c|c|c|c|c|c|c|c|}
\hline Authors & Year & Country & Design & Program & Objective & Target population & Strategy \\
\hline $\begin{array}{l}\text { Bugental DB, } \\
\text { et al. }{ }^{(35)}\end{array}$ & 2009 & USA & $\begin{array}{l}\text { Randomized } \\
\text { clinical study }\end{array}$ & $\begin{array}{l}\text { Healthy Start } \\
\text { home visitation }\end{array}$ & Intervention & $\begin{array}{l}\text { Families with } \\
\text { newborn children }\end{array}$ & $\begin{array}{l}\text { Home visitation } \\
\text { program, Parenting } \\
\text { development } \\
\text { program }\end{array}$ \\
\hline $\begin{array}{l}\text { Olds DL, } \\
\text { et al. }{ }^{(37)}\end{array}$ & 1986 & USA & $\begin{array}{l}\text { Randomized } \\
\text { clinical study }\end{array}$ & $\begin{array}{l}\text { Program of } \\
\text { prenatal and } \\
\text { infancy home } \\
\text { visitation by } \\
\text { nurses }\end{array}$ & Prevention & $\begin{array}{l}\text { Children }(0-2 \text { years }) \\
\text { of teenage } \\
\text { primiparous } \\
\text { mothers, of low } \\
\text { socioeconomic status }\end{array}$ & $\begin{array}{l}\text { Home visitation } \\
\text { program }\end{array}$ \\
\hline $\begin{array}{l}\text { Duggan A, } \\
\text { et al. }{ }^{(38)}\end{array}$ & 2004 & USA & $\begin{array}{l}\text { Randomized } \\
\text { clinical study }\end{array}$ & $\begin{array}{l}\text { Hawaii Healthy } \\
\text { Start Program } \\
(\mathrm{HSP})\end{array}$ & Prevention & $\begin{array}{l}\text { Families identified } \\
\text { at risk for violence } \\
\text { against children } \\
\text { according to the } \\
\text { Kempe's Family } \\
\text { Stress Checklist }\end{array}$ & $\begin{array}{l}\text { Home visitation } \\
\text { program }\end{array}$ \\
\hline $\begin{array}{l}\text { DuMont K, } \\
\text { et. al. }{ }^{(39)}\end{array}$ & 2008 & USA & $\begin{array}{l}\text { Randomized } \\
\text { clinical study }\end{array}$ & $\begin{array}{l}\text { Healthy Families } \\
\text { New York (HFNY) }\end{array}$ & Prevention & $\begin{array}{l}\text { Children }(0-2 \text { years }) \\
\text { and families with } \\
\text { teenage mothers }\end{array}$ & $\begin{array}{l}\text { Home visitation } \\
\text { program, Parenting } \\
\text { development } \\
\text { program }\end{array}$ \\
\hline $\begin{array}{l}\text { Bugental DB, } \\
\text { et al. }{ }^{(40)}\end{array}$ & 2002 & USA & $\begin{array}{l}\text { Randomized } \\
\text { clinical study }\end{array}$ & $\begin{array}{l}\text { Healthy Start } \\
\text { Program }\end{array}$ & Prevention & $\begin{array}{l}\text { Families with } \\
\text { increased risk } \\
\text { for child abuse, } \\
\text { according to the } \\
\text { Family Stress } \\
\text { Checklist (FSC) }\end{array}$ & $\begin{array}{l}\text { Home visitation } \\
\text { program, Parenting } \\
\text { development } \\
\text { program }\end{array}$ \\
\hline $\begin{array}{l}\text { Barlow J, } \\
\text { et al. }{ }^{(41)}\end{array}$ & 2007 & England & $\begin{array}{l}\text { Randomized } \\
\text { clinical study } \\
\text { multi-center, } \\
\text { with economic } \\
\text { assessment }\end{array}$ & - & $\begin{array}{l}\text { Identification } \\
\text { and prevention }\end{array}$ & $\begin{array}{l}\text { Children ( } 0-1 \text { year) } \\
\text { of teenage mothers } \\
\text { who started in } \\
\text { the program at six } \\
\text { months of pregnancy }\end{array}$ & $\begin{array}{l}\text { Home visitation } \\
\text { program, Parenting } \\
\text { development } \\
\text { program }\end{array}$ \\
\hline $\begin{array}{l}\text { Duggan A, } \\
\text { et al. }{ }^{(43)}\end{array}$ & 2007 & USA & $\begin{array}{l}\text { Randomized } \\
\text { clinical study }\end{array}$ & $\begin{array}{l}\text { Healthy Families } \\
\text { Alaska (HFAK) }\end{array}$ & Prevention & $\begin{array}{l}\text { Families with } \\
\text { children (0-2 years) }\end{array}$ & $\begin{array}{l}\text { Home visitation } \\
\text { program, Parenting } \\
\text { development } \\
\text { program }\end{array}$ \\
\hline $\begin{array}{l}\text { Lowell DI, } \\
\text { et al. }{ }^{(44)}\end{array}$ & 2011 & USA & $\begin{array}{l}\text { Randomized } \\
\text { clinical study }\end{array}$ & $\begin{array}{l}\text { Effectiveness test } \\
\text { of Child First } \\
\text { (a home-based } \\
\text { psychotherapeutic } \\
\text { intervention } \\
\text { based on a care } \\
\text { system) }\end{array}$ & Prevention & $\begin{array}{l}\text { Children }(6-36 \\
\text { months) }\end{array}$ & $\begin{array}{l}\text { Home visitation } \\
\text { program }\end{array}$ \\
\hline
\end{tabular}

Chart 2 - Types of programs and their main limitations and potentialities. São Paulo, SP, Brazil, 2018.

\begin{tabular}{|c|c|c|c|}
\hline Strategy & Description & Potentialities & Limitations \\
\hline $\begin{array}{l}\text { Home Visitation } \\
\text { Programs }\end{array}$ & $\begin{array}{l}\text { They usually start in the prenatal period; } \\
\text { families at high risk for violence are visited } \\
\text { at home by a primary care nurse or another } \\
\text { trained professional. }\end{array}$ & $\begin{array}{l}\text { They can include and understand } \\
\text { family dynamics. } \\
\text { They have been appointed as } \\
\text { programs for the identification and } \\
\text { prevention for domestic violence, } \\
\text { especially when started in the prenatal } \\
\text { period. }\end{array}$ & $\begin{array}{l}\text { Families that refuse to receive } \\
\text { visitors. } \\
\text { Effects on children of long-term } \\
\text { reduction of domestic violence } \\
\text { are still unknown. }\end{array}$ \\
\hline $\begin{array}{l}\text { Parenting Development } \\
\text { Programs }\end{array}$ & $\begin{array}{l}\text { They are usually group-based programs } \\
\text { and provide tools for parents to promote } \\
\text { healthy development of children and specific } \\
\text { parenting skills. }\end{array}$ & $\begin{array}{l}\text { They can influence family dynamics. } \\
\text { Perinatal education. }\end{array}$ & $\begin{array}{l}\text { Few studies are available } \\
\text { addressing the effectiveness of } \\
\text { these programs in long-term } \\
\text { reduction of domestic violence. }\end{array}$ \\
\hline $\begin{array}{l}\text { Programs for Children } \\
\text { Exposed to Violence }\end{array}$ & $\begin{array}{l}\text { Interventions developed with children } \\
\text { who are victims of violence or who have } \\
\text { witnessed violence. They are basically } \\
\text { individual therapeutic interventions, } \\
\text { conducted in groups or with the family. }\end{array}$ & $\begin{array}{l}\text { Field of consolidated literature. } \\
\text { They are effective in the short term } \\
\text { and potentially effective in the long } \\
\text { term. }\end{array}$ & $\begin{array}{l}\text { It is not known whether the } \\
\text { short-term positive effects } \\
\text { will actually remain until } \\
\text { adulthood, because there are } \\
\text { only studies assessing short- } \\
\text { term effects. }\end{array}$ \\
\hline
\end{tabular}


"This intervention may have the potential to improve parenting and increase the identification of children at risk of abuse and neglect in vulnerable families (...) low income, low education level, teenage mothers (...)."(41)

The conception of childhood and elements of gender issues were identified in the perspective of multi-causality. Childhood is understood as a chronological, ahistorical and universal framework in the health approach. Also, the health actions described in the programs are focused on singular dimension, in a perspective of the mother's responsibility, which reinforces the cultural and social standards and symbols that define the social roles assigned to the sexes:

“(...) children aged 2 to 12 years.”(30)

"if the child met the following criteria: age $6-36$ months $(. . .)^{\prime(44)}$

"an opportunity to avoid recognized neurological and psychological vulnerabilities presented by children when they are exposed to ongoing violence."(21)

“(...) families traced when the children were 8 and 16 months old $(\ldots))^{(43)}$.

"Domestic violence has a strong impact on children, as children exposed to domestic violence tend to present high levels of PTSD symptoms as well as other psychosocial issues. Domestic violence (DV) has implications for children, family systems and society as a whole; therefore, treating symptoms as a result of DV is extremely important."(23)

"It was developed to prevent or reduce serious emotional disturbances, developmental and learning disabilities, and abuse and neglect."(44)

"Differences in treatment for child abuse and neglect and emergency care were more significant among women who had less control (lower sense) over their lives." ${ }^{(37)}$.

\section{DISCUSSION}

Studies show domestic violence during childhood have a negative impact on the child's physical and mental health, with implications in adult life ${ }^{(46)}$, and these children are more likely to become victims or perpetrators of violence as adults ${ }^{(47)}$. Post-traumatic stress disorder (PTSD) has been observed among children who witnessed single episodes of violence, and in children who are daily exposed to violence ${ }^{(48)}$. A study conducted in the United States with 2,798 children and women found that $25 \%$ of children exposed to violence reported clinical symptoms of PTSD, $12 \%$ reported subclinical levels, and $47 \%$ of mothers reported clinical levels of stress related to motherhood after abuse, suggesting that mother-child interventions are required ${ }^{(49)}$.

These findings are consistent with our study, as most programs aiming to prevent, interfere or respond to violence were focused on the child and the family, especially the mother-child binomial, either in the prenatal period to prevent children from experiencing situations of violence, or in direct interventions with children.
The programs of intervention and response to violence were developed in high-income countries, and were focused on children; however, its long-term effects have not been fully studied. A review that investigated interventions with women in situations of violence also reported the same findings after analyzing the methodological quality of 84 studies conducted in high-, middle-, and low-income countries. It showed a large difference in the focus of interventions found in low- and middle-income countries when compared to high-income countries. Studies carried out in high-income countries are focused on response to violence, that is, on providing care to victims. In these countries, interventions are developed for women surviving violence: the victim receives psychosocial and legal support, counseling and home visits. These interventions have successfully improved the physical and mental health of victims and have increased the use of health services. However, this type of strategy has not reduced the number of victims, according to the authors of the review ${ }^{(50)}$.

One study highlights the most promising approaches are centered on the child, as they recognize and build natural or innate coping methods of the child. The same authors point out that family therapy based on the principles of CognitiveBehavioral Therapy, may be the most suitable approach to teach coping strategies to children ${ }^{(51)}$. Most "programs for children exposed to violence" and "programs for parenting development" use the principles and/or tools of behavioral therapy and are focused on the child.

Most Family Programs aimed to identify and prevent violence, focused on the family and the mother-child binomial. All programs used the same strategy to identify families who could benefit from the program, using standardized instruments and risk factors, only differing in program duration, inclusion criteria, and follow-up ${ }^{(35-39,41-44,51-53)}$. Most programs started in the prenatal period and ended in the post-partum period, or started in the prenatal period and ended when the child at 36 months of age.

Being a mother for the first time and getting pregnant during adolescence without a stable relationship is considered a risk factor for violence against children in the programs; for this reason, most programs involve children and their mothers. Cultural issues present in Japanese families, such as being more reserved and placing more responsibility in the hands of mothers, are often obstacles for the actions of public health nurses ${ }^{(33)}$. However, the study did not discuss gender issues involved the phenomenon of violence. Patriarchal family structures that define women as the sole responsible figure for child raising and behavior, while men are exempt from this responsibility, can lead to abuse committed by mothers.

A study that analyzed data from reports issued by the Network for the Protection of Children and Adolescents at Risk for Violence in the city of Curitiba, Brazil, showed that women (mothers or caregivers) are most often responsible for child neglect. However, when assessing these data in a gender perspective, the authors discuss the social roles assigned to women, as caregivers of the family and home; 
and when they fail in this task, they are always considered the only responsible persons for child neglect ${ }^{(15)}$.

Among the professionals who provide care to children who are victims of domestic violence, nurses are highlighted in all studies included in the review, acting as a connection with other workers, the family, and the care network. Studies have pointed out some conditions that limit the actions of nurses in dealing with violence against children, such as work overload, lack of support from other services, and lack of clarity in actions and conceptual definition of child maltreatment ${ }^{(54-57)}$.

The programs also highlight the importance of integrated work between health professionals and workers from different areas, such as education, social work, legal, and psychology. Multidisciplinary and interdisciplinary work is considered a tool to address violence against children.

Most programs had limitations such as lack of information about the long-term effects of interventions, which can be related to the incorporation of theoretical frameworks that do not help overcome the reality for social phenomena, such as violence.

The findings of this review helped identify potential aspects of programs addressing violence against children in primary health care. However, these programs have a limited understanding of the needs of social groups, since they are based on homogeneously standardized risk factors and instruments which do not consider the existing heterogeneous reality and cannot effectively identify more exposed groups, not providing tools to overcome this reality. One study showed that municipal administration instruments will only be able to perform health actions that reduce inequality when the perspective of Social Determination of the HealthDisease Process is incorporated to help understand health ${ }^{(58)}$.

Another study that addressed the phenomenon of violence against children, like our study, showed the incorporation of other theoretical frameworks to understand health, not based on universal actions and risk factors, has a real impact on the transformation of social phenomena and responses to the health needs of children and their families ${ }^{(59)}$.
Authors from Nursing in Collective Health defend the use and association of powerful analytical categories to elucidate phenomena linked with the methods of social production and reproduction, so that health actions can actually have long-term positive effects. Discussions about gender, generation and power relations and subordination, despite poorly explored in the world scientific literature, can contribute to other perspectives while addressing the phenomenon of domestic violence against children. In Brazil, studies have more consistently addressed both the gender and generational perspectives in the phenomenon of domestic violence against children ${ }^{(15,18,55,60-61)}$.

Given the limitation of other theoretical-methodological frameworks to capture all determinations of the phenomenon of violence against children, it is extremely important to expand the understanding of the health-disease process in a socially determined manner in the development of programs addressing violence against children ${ }^{(45,58,59)}$.

The limitations of this review refer to the required update in database search that was performed in 2018, non-use of "health promotion" in the search strategy, and the fact that studies developed in Latin America and the Caribbean were not found in the search.

\section{CONCLUSION}

The programs found in this review were well structured and essential for addressing domestic violence against children. They used the same approach to identify situations of violence and vulnerable children and families, and adopted a multi-causal concept to understand the health-disease process. Nursing professionals were highlighted as the workers with the potential ability to identify and interfere in situations of violence, and to perform interventions articulating different support networks.

Incorporating theoretical frameworks that consider methods of social production and reproduction and reveal subordination of generation and gender can help explain the phenomenon of violence against children and support the development of programs to transform and overcome the objective reality.

\section{RESUMO}

Objetivo: Mapear as bases conceituais orientadoras dos programas de enfrentamento da violência contra a criança desenvolvidos na Atenção Primária à Saúde. Método: Revisão de escopo que seguiu as recomendações metodológicas do Instituto Joanna Briggs. Para gerenciamento e análise dos dados, foi utilizado um software de análise qualitativa e um gerenciador de referências. Resultados: 1.346 estudos foram pré-selecionados e analisados. A amostra final foi composta por 24 estudos publicados majoritariamente na década de 2000. Foram identificadas três estratégias de atuação dos programas: "Visita Domiciliária", "Crianças Expostas à Violência" e "Desenvolvimento da Parentalidade", a maioria com foco no nível da Intervenção. Nenhum estudo explicitou as bases conceituais orientadoras dos programas. Conclusão: Os programas de enfrentamento mostraram-se bem estruturados e fundamentais para o enfrentamento da violência doméstica contra a criança. Adotaram, sobretudo, a concepção multicausal para a compreensão do processo saúde-doença, restritiva para a superação das contradições do fenômeno da violência.

\section{DESCRITORES}

Violência Doméstica; Maus-tratos Infantis; Atenção Primária à Saúde; Saúde Pública; Revisão; Enfermagem.

\section{RESUMEN}

Objetivo: Mapear las bases conceptuales orientadoras de programas de enfrentamiento de violencia contra el niño desarrollados en Atención Primaria de Salud. Método: Revisión de alcance conforme recomendaciones metodológicas del Instituto Joanna Briggs. Para gestión y análisis de los datos se utilizó software de análisis cuantitativo y un gestor de referencias. Resultados: Fueron preseleccionados y analizados 1.346 estudios. La muestra final estuvo integrada por 24 trabajos, publicados mayoritariamente en la década de 2000. 
Fueron identificadas tres estrategias de actuación de los programas "Visita Domiciliaria", "Niños Expuestos a la Violencia” y "Desarrollo de la Parentalidad”, la mayoría con fono en el nivel de Intervención. Ningún estudio explicó las bases conceptuales orientadoras de los programas. Conclusión: Los programas de enfrentamiento se mostraron bien estructurados y fundamentados para enfrentar la violencia doméstica contra el niño. Adoptaron la concepción multicausal para comprender el proceso salud-enfermedad, restrictiva para superar las contradicciones del fenómeno de la violencia.

\section{DESCRIPTORES}

Violencia Domestica; Maltrato a los Niños; Atención Primaria de Salud; Salud Pública; Revisión; Enfermería.

\section{REFERENCES}

1. Odalia N. O que é violência. São Paulo: Brasiliense; 1983.

2. Dahlberg LL, Krug EG. Violence: a global public health problem. In: Krug EG, Dahlberg LL, Mercy JA, Zwi AB, Lozano R, editors. World report on violence and health. Geneva: WHO; 2002. p.3-21.

3. Unicef - Fundo das Nações Unidas para a Criança - Brasil. A cada 7 minutos, uma criança ou um adolescente morre vítima da violência [Internet]. 2017 [cited 2018 Nov 15]. Available from: https://www.unicef.org/brazil/pt/media_37371.html

4. Unicef - United Nations Children's Fund. A familiar face: violence in the lives of children and adolescents. [Internet]. New York; 2017 [cited 2020 Jan 10]. Available at: https://www.unicef.org/publications/index_101397.html.

5. OMS - Organización Mundial de la Salud. Maltrato infantil [Internet]. 2016 [cited 2018 Nov 01]. Available from em: http://www.who. int/mediacentre/factsheets/fs150/es/.

6. Minayo MCS. Trajetória histórica de inclusão da violência na agenda do setor saúde. In: Minayo MCS, Deslandes SF. Análise diagnóstica da Política Nacional de Saúde para redução de acidentes e violências. Rio de Janeiro: Fiocruz; 2007. p.17-30.

7. Nunes CB, Sarti CA, Ohara CVS. Profissionais de saúde e violência intrafamiliar contra a criança e adolescente. Acta Paul Enferm. 2009;22(n. esp):903-8. DOI: http://dx.doi.org/10.1590/S0103-21002009000700012

8. Oliveira RNG, Fonseca RMGS. Health needs: the interface between the discourse of health professionals and victimized women. Rev Latino-Am Enfermagem. 2015;23(2):299-306. DOI: 10.1590/0104-1169.3455.2555

9. Signorelli MC, Auad D, Pereira PPG. Domestic violence against women and professional intervention in primary healthcare: an etnographic study in Matinhos, Paraná State, Brazil. Cad Saude Publica [Internet]. 2013 [cited 2020 Jan 10];29(6):1230-40. Available from: https:// scielosp.org/pdf/csp/2013.v29n6/1230-1240/pt

10. d'Oliveira AFPL, Schraiber LB, Hanada H, Durand J. Comprehensive health (care) services to women in gender violence situation: an alternative to primary health care. Cienc Saude Colet. 2009;14(4):1037-50. DOI: 10.1590/s1413-81232009000400011

11. Apostólico MR, Hino P, Egry EY. As possibilidades de enfrentamento da violência infantil na consulta de enfermagem sistematizada. Rev Esc Enferm USP. 2013;47(2):320-7. DOI: http://dx.doi.org/10.1590/S0080-62342013000200007

12. Egry EY, Apostólico MR, Morais TCP. Notificação da violência infantil, fluxos de atenção e processo de trabalho dos profissionais da Atenção Primária em Saúde. Cienc Saude Colet. 2018;23(1):83-92. DOI: https://doi.org/10.1590/1413-81232018231.22062017

13. Souza HS. O processo de trabalho em enfermagem sob o fluxo tensionado. In: Souza HS, Mendes A, organizadores. Trabalho e saúde no capitalismo contemporâneo: enfermagem em foco. Rio de Janeiro: DOC Content; 2016. p. 87-111.

14. Breilh J. Entrevista: Jaime Breilh. Trab Educ Saúde [Internet]. 2015 [cited 2017 Dec 18]; 13(2):533-40. Available from: http://www.scielo. br/pdf/tes/v13n2/es_1981-7746-tes-1302-0533.pdf

15. Egry EY, Apostólico MR, Albuquerque LM, Gessner R, Fonseca RMGS. Understanding child neglect in a gender context: a study performed in a Brazilian city. Rev Esc Enferm USP. 2015;49(4):556-63. DOI: http://dx.doi.org/10.1590/S0080-623420150000400004

16. Egry EY, Nichiata LYI. 30 anos de Enfermagem em Saúde Coletiva. [Editorial]. Rev Bras Enferm. 2018;71(Suppl 1):463-4. DOI: http:// dx.doi.org/10.1590/0034-7167-201871sup101

17. Peters MDJ, Godfrey C, Mclnerney P, Baldini Soares C, Khalil H, Parker D. Chapter 11: Scoping Reviews. In: Aromataris E, Munn Z, editors. Joanna Briggs Institute Reviewer's Manual. The Joanna Briggs Institute [Internet]. 2017 [cited 2020 Jan 10]. Available from: https:// reviewersmanual.joannabriggs.org/

18. Egry EY, Fonseca RMGS, Oliveira MAC. Ciência, Saúde Coletiva e Enfermagem: destacando as categorias gênero e geração na episteme da práxis. Rev Bras Enferm. 2013;66(n. esp):119-33. DOl: http://dx.doi.org/10.1590/S0034-71672013000700016.

19. Bardin L. Análise de conteúdo. São Paulo: Edições 70; 2011.

20. Moher D, Liberati A, Tetzlaff J, Altman DG; PRISMA Group. Preferred reporting items for systematic reviews and meta-analyses: The PRISMA statement. PLoS Med. 2009;6(7):e1000097. DOI: 10.1371/journal.pmed.1000097

21. Bunston W. The Peek A Boo Club: Group work for Infants and Mothers Affected by Family Violence. DVIRC Quarterly; [Internet]. 2006 [cited 2020 Jan 10].;1:3-8. Available from: http://citeseerx.ist.psu.edu/viewdoc/download?doi=10.1.1.576.4444\&rep=rep1\&type=pdf

22. Finkelstein N, Rechberger E, Russell LA, VanDeMark NR, Noether CD, O'Keefe M, et al. Building resilience in children of mothers who have Co-occurring Disorders and histories of Violence. The Journal of Behavioral Health Services \& Research. 2005;32(2):141-154. DOI: https://doi.org/10.1007/BF02287263

23. Puccia E, Redding TM, Brown RS, Gwynne PA, Hirsh AB, Frances RJH, et al. Using Community Outreach and Evidenced-Based Treatment to Address Domestic Violence Issues. Soc Work Ment Health. 2012;10(2):104-26. DOI: https://doi.org/10.1080/15332985.2011.601704

24. Sharp C, Jones J, Netto G, Humphreys C. We Thought They Didn't See: Cedar in Scotland-Children and Mothers Experiencing Domestic Abuse Recovery evaluation report, 2011. Available from: https://www.cedarnetwork.org.uk/wp-content/uploads/2011/03/EvaluationReport-DOWNLOAD1.pdf 
25. Crusto CA, Lowell DI, Paulicin B, Reynolds J, Feinn R, Friedman SR, et al. Evaluation of a Wraparound Process for Children Exposed to Family Violence. Best Pract Ment Health. 2008;4(1):1-18.

26. Child Trends. Trauma-Focused Cognitive Behavioural Therapy (TF-CBT) [Internet]. 2016 [cited 2017 Dec 18]. Available from: https:// www.childtrends.org/?programs=trauma-focused-cognitive-behavioral-therapy-tf-cbt

27. Becker KD, Mathis G, Mueller CW, Issari J, Atta SS. Community-Based Treatment Outcomes for Parents and children Exposed to Domestic Violence. Journal of Emotional Abuse. 2008;8(1-2):187-204.

28. CEBC - California Evidence-Based Clearinghouse for Child Welfare. Kids' Club and Moms' Empowerment [Internet]. 2015. [cited 2017 Dec 18]. Available from: http://www.cebc4cw.org/program/kids-club-moms-empowerment/detailed

29. Mejdoubi J, van den Heijkant SC, van Leerdam FJ, Heymans MW, Crijnen A, Hirasing RA. The effect of VoorZorg, the Dutch nurse-family partnership, on child maltreatment and development: a randomized controlled trial. PloS One. 2015;10(4):e0120182. DOI: https://doi. org/10.1371/journal.pone.0120182

30. Kendall S, Bloomfield L, Appleton J, Kitaoka K. Efficacy of a group-based parenting program on stress and self-efficacy among Japanese mothers: a quasi-experimental study. Nurs Health Sci. 2013;15(4):454-60. DOI: https://doi.org/10.1111/nhs.12054

31. Crisp BR, Lister PG. Child protection and public health: nurses' responsibilities. J Adv Nurs. 2004;47(6):656-63.

32. MacMillan HL, Thomas BH, Jamieson E, Walsh CA, Boyle MH, Shannon HS et al. Effectiveness of home visitation by public-health nurses in prevention of the recurrence of child physical abuse and neglect: a randomised controlled trial. Lancet. 2005;365(9473):1786-93.

33. Kayama M, Sagami A, Watanabe Y, Senoo E, Ohara M. Child abuse prevention in Japan: an approach to screening and intervention with mothers. Public Health Nurs. 2004;21(6):513-8. DOI: https://doi.org/10.1111/j.0737-1209.2004.21602.x

34. Kelleher L, Johnson M. An evaluation of a volunteer-support program for families at risk. Public Health Nurs. 2004;21(4):297-305.

35. Bugental DB, Schwartz A. A cognitive approach to child mistreatment prevention among medically at-risk infants. Dev Psychol. 2009;45(1):284-8. DOI: https://doi.org/10.1037/a0014031

36. Olds DL, Kitzman H, Hanks C, Cole R, Anson E, Sidora-Arcoleo K, et al. Effects of nurse home visiting on maternal and child functioning: age-9 follow-up of a randomized trial. Pediatrics. 2007;120(4):e832-45. DOI: https://doi.org/10.1542/peds.2006-2111

37. Olds DL, Henderson CR Jr, Chamberlin R, Tatelbaum R. Preventing child abuse and neglect: a randomized trial of nurse home visitation. Pediatrics [Internet]. 1986 [cited 2020 Jan 10];78(1):65-78. Available from: https://pediatrics.aappublications.org/content/ pediatrics/78/1/65.full.pdf

38. Duggan A, McFarlane E, Fuddy L, Burrell L, Higman SM, Windham A, et al. Randomized trial of a statewide home visiting program: impact in preventing child abuse and neglect. Child Abuse Negl. 2004;28(6):597-622. DOI: https://doi.org/10.1016/j.chiabu.2003.08.007

39. DuMont K, Mitchell-Herzfeld S, Greene R, Lee E, Lowenfels A, Rodriguez M, et al. Healthy Families New York (HFNY) randomized trial: effects on early child abuse and neglect. Child Abuse Negl. 2008;32(3):295-315. DOI: https://doi.org/10.1016/j.chiabu.2007.07.007

40. Bugental DB, Ellerson PC, Lin EK, Rainey B, Kokotovic A, O'Hara N. A cognitive approach to child abuse prevention. J Fam Psychol. 2002;16(3):243-58.

41. Barlow J, Davis H, McIntosh E, Jarrett P, Mockford C, Stewart-Brown S. Role of home visiting in improving parenting and health in families at risk of abuse and neglect: results of a multicentre randomised controlled trial and economic evaluation. Arch Dis Child. 2007;92(3): 229-33. DOI: https://doi.org/10.1136/adc.2006.095117

42. Fergusson DM, Grant H, Horwood LJ, Ridder EM. Randomized trial of the Early Start program of home visitation. Pediatrics. 2005;116(6):e803-9. DOI: https://doi.org/10.1542/peds.2005-0948

43. Duggan A, Caldera D, Rodriguez K, Burrell L, Rohde C, Crowne SS. Impact of a statewide home visiting program to prevent child abuse. Child Abuse Negl. 2007;31(8):801-27. DOI: https://doi.org/10.1016/j.chiabu.2006.06.011

44. Lowell DI, Carter AS, Godoy L, Paulicin B, Briggs-Gowan MJ. A randomized controlled trial of Child FIRST: a comprehensive home-based intervention translating research into early childhood practice. Child Dev. 2011;82(1):193-208. DOI: https://doi.org/10.1111/j.14678624.2010.01550.x.

45. Fonseca RMGS, Egry EY, Bertolozzi MR. O Materialismo Histórico e Dialético como Teoria da Cognição e Método para a compreensão do Processo Saúde-Doença. In: Egry EY, Cubas MR, organizadoras. O Trabalho da Enfermagem em Saúde Coletiva no Cenário CIPESC: guia para pesquisadores. Curitiba: ABEn-PR; 2006. p. 19-61.

46. Wells L, Claussen C, Cooper M. Domestic \& sexual violence: A background paper on primary prevention programs and frameworks. Calgary, AB: The University of Calgary, Shift: The Project to End Domestic Violence [Internet]. 2012 [cited 2020 Jan 10]. Available from: https://dspace.ucalgary.ca/bitstream/handle/1880/51943/R3_Shift_2012_DV_SV_Prevention_Programs_and_Frameworks.pdf;jsessionid= DFAD4280698162BF1629DBA228B1F66C?sequence=3

47. Stanley N. Children experiencing domestic violence: a research review. Dartington: Research in Practice [Internet]. 2011 [cited 2020 Jan 10]. Available from: https://pdfs.semanticscholar.org/b87f/ba324bd96d83fe1dc892ace1eede3822b92e.pdf

48. Guille L. Men who batter and their children: An integrated review. Aggress Violent Behav. 2004;9(2):129-63. DOI: https://doi.org/10.1016/ S1359-1789(02)00119-2

49. Kaufman JS, Ortega S, Schewe PA, Kracke K, Safe Start. Demonstration Project Communities. Characteristics of young children exposed to violence: The safe start demonstration project. J Interpers Violence. 2011;26(10):2042-72. DOI: https://doi.org/10.1177/0886260510372942

50. Ellsberg M, Arango DJ, Morton M, Gennari F, Kiplesund S, Contreras M, et al. Prevention of violence against women and girls: what does the evidence say? Lancet. 2015;385:(9977):1555-66. DOI: https://doi.org/10.1016/S0140-6736(14)61703-7

51. Koniak-Griffin D, Verzemnieks IL, Anderson NL, Brecht ML, Lesser J, Kim S, et al. Nurse visitation for adolescent mothers: two-year infant health and maternal outcomes. Nurs Res. 2003;52(2):127-36. DOI: https://doi.org/110.1097/00006199-200303000-00009 
52. Armstrong KL, Fraser JA, Dadds MR, Morris J. A randomized, controlled trial of nurse home visiting to vulnerable families with newborns. J Paediatr Child Health. 1999;35(3):237-44. DOI: https://doi.org/10.1046/j.1440-1754.1999.00348.x

53. Siegel E, Bauman KE, Schaefer ES, Saunders MM, Ingram DD. Hospital and home support during infancy: impact on maternal attachment, child abuse and neglect, and health care utilization. Pediatrics [Internet] 1980 [cited 2020 Jan 10];66(2):183-90. Available from: https:// pediatrics.aappublications.org/content/pediatrics/66/2/183.full.pdf

54. Carlos DM, Pádua EMM, Ferriani MGC. Violence against children and adolescents: the perspective of Primary Health Care. Rev Bras Enferm. 2017;70(3):511-8. DOI: http://dx.doi.org/10.1590/0034-7167-2016-0471

55. Carlos DM, Ferriani MGC. Family violence against children and adolescents in context: how the territories of care are imbricated in the picture. Rev Latino-Am Enfermagem [Internet]. 2016 [cited 2018 Oct 19];24:e2735. DOI: http://dx.doi.org/10.1590/1518-8345.0593.2735

56. Maia JN, Ferrari RAP, Gabani FL, Tacla MTGM, Reis TB, Fernandes MLC. Violence against children: the routine of the professionals in the primary health care. Rev Rene. 2016;17(5):593-601. DOI: https://doi.org/10.15253/2175-6783.2016000500003

57. Hooker L, Small R, Humphreys C, Hegarty K, Taft A. Applying normalization process theory to understand implementation of a family violence screening and care model in maternal and child health nursing practice: a mix method process evaluation of a randomised controlled trial. Implement Sci. 2015;10:39. DOI: https://doi.org/10.1186/s13012-015-0230-4

58. Nascimento AB, Egry EY. Os planos municipais de saúde e as potencialidades de reconhecimento das necessidades em saúde: estudo de quatro municípios brasileiros. Saude soc. [Internet]. 2017 [cited 2019 Aug 05];26(4):861-871. Available from: http://www.scielo.br/scielo. php?script=sci_arttext\&pid=S0104-12902017000400861\&lng=en.

59. Sakata-So KN, Silva MG, Egry EY, Cubas MR, Albuquerque LM. Subconjunto terminológico para o enfrentamento da violência doméstica contra a criança: um estudo de validação [internet]. In: Atas - Investigação Qualitativa em Saúde/Investigación Cualitativa en Salud, 2019 [cited 2020 Jan 10];2:1000-09. Available from: https://proceedings.ciaiq.org/index.php/CIAIQ2019/article/view/2174/2102

60. Lourenço RG, Fornari LF, Santos DLA, Fonseca RMGS. Community interventions related to intimate partner violence among adolescents: scope review. Rev. Bras. Enferm. [Internet]. 2019 Feb [cited 2019 May 04];72(1):277-286. Available from: http://www.scielo.br/scielo. php?script=sci_arttext\&pid=S0034-71672019000100277\&lng=en. DOI: https://doi.org/10.1590/0034-7167-2018-0586.

61. Fornari LF, Lourenço RG, Fonseca RMGS, Santos DLA, Egry EY. Gender perspective in reports on women athletes in rio 2016 olympic games. Texto contexto - enferm. [Internet]. 2019 [cited 2019 May 04];28:e20180170. Available from: http://www.scielo.br/scielo. php?script=sci_arttext\&pid=S0104-07072019000100348\&Ing=en. 